BARCELONA SUMMER '88

\author{
Mediterranean Institute \\ July $4-29,1988$ \\ "Professionalism and Research"
}

A unique opportunity for EFL/ESL teachers of the world to enhance their professional skills. Internationally recognized staff from European and American universities present a wide selection of practical and advanced courses of interest to all those professionally involved in English Language Teaching.

The Mediterranean Institute includes courses in

- professional language teaching skills;

- innovative language teaching practices and new media applications;

- a wide range of research areas and techniques; and

- teacher training.

Jointly organized by the Teachers College of Columbia University, the University of London Institute of Education, the University of Barcelona, and ESADE of Barcelona.

For an Institute brochure with programming, enrollment details, and further information, please write to:

E. P. Mills

ESADE

AV. Pedraibes, 60-62

08034 Barcelona, Spain

(tel) 3442036404 


\section{APPLIED PSYCHOLINGUISTICS}

\section{INSTRUCTIONS TO AUTHORS}

The Editors of Applied Psycholinguistics are Catherine E. Snow, Harvard Graduate School of Education, and John L. Locke, Massachusetts General Hospital. Authors should submit their original manuscript plus three copies to:

\section{Applied Psycholinguistics, Editorial Office}

Harvard Graduate School of Education

Larsen Hall, 7th Floor

Cambridge, MA 02138

Submissions may be full length articles (original research, theoretical or methodological studies, issue-oriented literature reviews), short notes, or critical responses to articles previously published in Applied Psycholinguistics.

Spelling, capitalization, and punctuation should be consistent within each article and each note, and should follow the style recommended in the Third Edition of the Publication Manual of the American Psychological Association. A title should be given for each article and note. An auxiliary short title should be given for any article or note whose title exceeds 50 characters. The author's name should be given in the form preferred for publication; the affiliation should include the author's full mailing address. An abstract should be prepared for each article (limited to 120 words). Author's note(s) appear in the acknowledgment section. Tables and figures (which comprise photographs, charts, or other artwork) should be numbered consecutively throughout the article or note. Bibliographic citations in the text must include the author's last name and the date of publication and may include page references. Complete bibliographic information for each citation should be included in the list of references. Examples of correct styling for bibliographic citations are: Brown (1973), Ingram (1976, 54-55), Smith and Miller (1966), (Smith \& Miller, 1966), (Peterson, Danner, \& Flavell, 1972) and subsequently (Peterson et al., 1972). If more than one, citations should be in alphabetical order. References should be typed in alphabetical order using the style of the following examples:

Brown, R. (1973). Schizophrenia, language and reality. American Psychologist, 28, 395-403.

Ingram, D. (1976). Phonological disability in children. New York: Elsevier.

Krashen, S. D. (1978). Individual variation in the use of the Monitor. In W. C. Ritchie (Ed.), Second language acquisition research. New York: Academic. Smith, F., \& Miller, G. A. (Eds.). (1966). The genesis of language. Cambridge, MA: M.I.T. Press.

Titles of journals should not be abbreviated.

\section{Preparation of the manuscript}

The entire manuscript, including notes and references, should be typed double-spaced on $81 / 2$ by 11 inch or A4 paper, with margins set to accommodate approximately 70 characters per line and 25 lines per page. Each element of the article or note should begin on a new page and should be arranged as follows: title page (including title, short title, author's full name and affiliation, including mailing address), abstract, text, appendixes, acknowledgments, notes, references (including reference notes for unpublished citations), tables and figures with captions. Each table and figure should be submitted on a separate page. Manuscript pages should be numbered consecutively.

Figures should be ready for photographic reproduction; they cannot be redrawn by the printer. Charts, graphs, or other artwork should be drawn in black ink on white paper to occupy a standard area of $81 / 2$ by 11 or $81 / 2$ by $51 / 2$ inches before reduction. Photographs should be glossy black-and-white prints; 8 by 10 inch enlargements are preferred. All labels and details on figures should be clearly printed and large enough to remain legible after a $50 \%$ reduction. It is recommended that labels be done in transfer type of a san-serif face such as Helvetica.

Copyediting and proofreading

The publishers reserve the right to copyedit and proof all articles and notes accepted for publication. Authors will review their copyedited manuscripts only if changes have been substantial. Page proofs of articles and notes will be sent to authors for correction of typographical errors only; authors must notify the editorial office of any changes within 48 hours or approval will be assumed.

The Third Edition of the Publication Manual of the American Psychological Association should be consulted for instructions on aspects of manuscript preparation and style not covered in these instructions. The Editor may find it necessary to return for reworking and retyping manuscripts that do not conform to requirements.

Each author will receive 25 offprints of his or her article or note without charge; additional copies may be purchased if ordered at proof stage.

Submission of an article or note implies that it has not been published elsewhere. Authors are responsible for obtaining written permission to publish material (quotations, illustrations, etc.) for which they do not own the copyright. Contributors of accepted articles and notes will be asked to assign their copyrights, on certain conditions, to Cambridge University Press. 


\section{Applied Psycholinguistics Volume 9 Number 11988}

\section{Articles}

GIUSEPPE COSSU, DONALD SHANKWEILER, ISABELLE Y. LIBERMAN, LEONARD KATZ, and GIUSEPPE TOLA Awareness of phonological segments and reading ability in Italian children

MARGUERITE E. MALAKOFF The effect of language of instruction on reasoning in bilingual children

LAUURENCE B. LEONARD, LETIZIA SABBADINI, VIRGINIA VOLTERRA, and JEANETTE $S$. LEONARD Some influences on the grammar of English- and Italian-speaking children with specific language impairment

IRENE M. PEPPERBERG An interactive modeling technique for acquisition of communication skills: Separation of "labeling" and "requesting" in a psittacine subject

MARGARET BRUCK and GLORIA WATERS An analysis of the spelling errors of children who differ in their reading and spelling skills

\section{Book Reviews}

WROLSTAD, M. E., and FISHER, D. F. (Eds.). (1986). Toward a new understanding of literacy (Insup Taylor)

VAN PEER, WILLIE (1986). Stylistics and psychology:

Investigations of foregrounding (Deborah A. Hicks)

NYSTRAND, MARTIN, with HIMLEY, MARGARET, and DOYLE, ANNE (1986). The structure of written communication: Studies in reciprocity between writers and readers (Jean Chandler)

MCLAUGHLIN, BARRY (1987). Theories of second language

learning (Michael Tomasello)

MACKAY, IAN (1986). Phonetics: The science of speech production. (John L. Locke)

(C) 1988 Cambridge University Press

\section{CAMBRIDGE UNIVERSITY PRESS}

The Edinburgh Building, Shaftesbury Road, Cambridge CB2 2RU, England 32 East 57 Street, New York, NY 10022, U.S.A.

10 Stamford Road, Oakleigh, Melbourne 3166, Australia

Printed in the United States of America 